\title{
KEBIJAKAN MONETER DALAM MENGATASI INFLASI DI INDONESIA
}

\author{
Farah Fauziyah \\ Lingkar Studi Ekonomi Syariah \\ farah.fauziyah@ymail.com
}

\begin{abstract}
This study aimed to analyze the transmission mechanism of monetary policy in control the inflation in Indonesia, both in terms of sharia and conventional. The analytical tools that used in this research is the Autoregessive Vector (VAR). This VAR research results conducted by Test Impulse Response Function (IRF) and the Test of Forecast Error Variance Decomposition (FEVD). IRF showed that the yield on the conventional side (Model I) is variable SBI had a negative impact and bonds provide a positive impact on inflation, while on the sharia (Model II) have a positive impact in terms of reducing inflation. Fluctuation on Islamic monetary transmission mechanism more stable than the conventional monetary policy transmission mechanism. FEVD the model I give a negative contribution in raising inflation about $43.86 \%$, while the second model of a positive contribution in the sense of lowering inflation about to $25.77 \%$. Therefore we can conclude sharia monetary policy transmission mechanism is better than conventional transmission mechanism of monetary policy.
\end{abstract}

Keywords: sharia monetary; conventional monetary; VAR; FEVD; IRF

\section{Abstrak}

Penelitian ini bertujuan untuk menganalisis mekanisme transmisi kebijakan moneter di Indonesia dalam mengendalikan inflasi, baik dilihat dari sisi syariah maupun konvensional. Alat analisis yang dipakai dalam penelitian ini adalah dengan Vector Autoregessive (VAR). Hasil penelitian VAR ini dilakukan dengan Uji Impulse Response Function (IRF) dan Uji Forecast Error Variance Decomposition (FEVD). Hasil IRF menunjukan bahwa pada konvensional (Model I) variabel SBI memberikan dampak negatif dan obligasi memberikan dampak positif terhadap inflasi (IHK), sedangkan pada sisi syariah (Model II) memberikan dampak positif dalam menurunkan inflasi. Gejolak pada mekanisme transmisi moneter syariah lebih cepat mereda dan stabil dibandingkan pada mekanisme transmisi kebijakan moneter konvensional. Untuk hasil uji FEVD pada model I menaikkan inflasi sebesar 43,86\%, sedangkan pada model II mampu menurunkan inflasi (IHK) sebesar 25,77\%. Sehingga mekanisme transmisi kebijakan moneter syariah lebih baik dibandingkan mekanisme transmisi kebijakan moneter konvensional.

Kata Kunci: moneter syariah; moneter konvensional; VAR; FEVD; IRF

Diterima: 12 Pebruari 2015; Direvisi: 28 Maret 2015; Disetujui: 7 April 2015 


\section{PENDAHULUAN}

Goncangan yang terjadi pada perekonomian global dapat mempengaruhi kondisi perekonomian nasional. Untuk mengurangi dampak goncangan perekonomian global terhadap perekonomian dalam negeri, dibutuhkan kebijakan yang efektif dan efisien baik kebijakan moneter maupun kebijakan fiskal diikuti dengan berbagai kebijakan ekonomi lainnya. Fokus penerapan kebijakan moneter di Indonesia sesuai dengan UU no. 23 tahun 1999 yang kemudian telah diubah dalam UU No. 3 tahun 2004 mengenai kebijakan moneter, disebutkan bahwa Bank Indonesia diberi amanah sebagai otoritas moneter ganda yang dapat menjalankan kebijakan moneter konvensional maupun syariah, maka kebijakan moneter yang ditempuh menggunakan dual monetary policy yakni konvensional dan syariah dengan tujuan utama kebijakan moneter di Indonesia adalah untuk mencapai dan memelihara kestabilan nilai rupiah, yaitu kestabilan harga (inflasi) dan nilai tukar rupiah.

Target atau sasaran inflasi merupakan tingkat inflasi yang harus dicapai oleh Bank Indonesia. Pada tahun 2011 dan tahun 2012 memiliki tingkat inflasi aktual yang sangat baik sebesar $3.79 \%$ dan $4.30 \%$, yaitu dibawah target inflasi. Sedangkan pada tingkat inflasi aktual tahun 2013 dan 2014 menunjukan angka secara umum telah mencapai $8.38 \%$ dan $8.36 \%$, hal ini menunjukan tingkat inflasi yang kurang baik dikarenakan angka inflasi ini jauh dari target tahun tersebut. Selain itu tingkat inflasi hampir mendekati angka 10\%. Sedangkan untuk tahun 2015, nilai tukar rupaiah meningkat sebesar Rp 13,500/dollar AS. Dalam hal ini dapat dikatakan target pencapaian inflasi pemerintah kurang maksimal dalam dua tahun terakhir ini, yaitu menuju sasaran inflasi yang rendah dan stabil.

Pemerintah menggunakan kebijakan moneter sebagai pengendali inflasi, yaitu stabilisasi harga. Oleh karena itu dibutuhkan adanya mekanisme tranasmisi kebijakan moneter beserta instrumen-instrumen yang digunakan. Terbentuknya sistem monter syariah diharapkan menjadi solusi dari kegagalan yang diakibatkan oleh sistem moneter konvensional yang terpaku pada sistem bunga. Sistem bunga membawa kegiatan perekonomian dalam tindak spekulasi yang akan menghambat perekonomian sektor riil untuk berkembang dan akhirnya pertumbuhan ekonomi tidak berdiri dengan kuat atau rapuh meskipun angka pertumbuhan ekonomi tinggi. Asumsinya adalah dengan adanya kebijakan moneter syariah, kebijakan moneter 
khususnya di Indonesia akan terbebas dari sistem bunga dan diharapkan dapat mencapai tujuan moneter yang lebih baik. Dalam penelitian ini mengkhususkan dengan menggunakan mekanisme transmisi moneter jalur harga aset. Penelitian dengan menggunakan jalur harga aset masih sedikit sekali dilakukan. Namun, terdapat studi mengenai bekerjanya transmisi moneter melalui saluran harga aset dilakukan oleh Idris dkk (2002). Mengatakan bahwa harga tanah dan properti sebetulnya merupakan indikator yang lebih baik untuk mengkaji saluran harga aset tersebut namun terbentur masalah data maka digunakanlah harga saham. Keterbatasan data tersebut maka penelitian ini menggunakan variabel obligasi dan sukuk sebagai indikator harga aset.

Kebijakan moneter melalui jalur harga aset adalah suatu kebijakan moneter yang juga akan mempengaruhi perkembangan harga-harga aset lain, baik harga aset financial seperti obligasi dan harga saham, maupun aset fisik khususnya harga properti dan emas. Perubahan suku bunga dan nilai tukar maupun besarnya investasi di pasar uang rupiah dan valuta asing akan berpengaruh pula terhadap volume dan harga obligasi, saham dan aset fisik tersebut, dan selanjutnya perkembangan tersebut akan berdampak pada berbagai aktivitas di sektor riil. Pengaruh harga aset pada konsumsi dan investasi akan mempengaruhi pula permintaan agregat dan pada akhirnya akan menentukan tingkat output riil dan inflasi dalam ekonomi. (Warjiyo, 2004).

Sebagai otoritas moneter, Bank Indonesia biasanya akan memainkan dan mengatur jumlah uang beredar untuk menstabilkan ekonomi moneter negara. Jumlah uang beredar yang stabil akan menekan tingginya angka inflasi. Uang yang beredar dalam suatu negara amat penting. Dalam arti luas, uang beredar adalah uang yang di dalamnya termasuk aset keuangan yang memenuhi fungsinya sebagai uang dengan tingkat liquiditas yang berbeda satu sama lain. Data terakhir pada tahun 2014 dari Bank Indonesia jumlah uang beredar (M2) mencapai $\mathrm{Rp}$ 4.170.731 miliar, meningkat dari tahun sebelumnya sebanyak Rp 3.730.197 miliar. Hal tersebut terjadi karena naik turunnya angka pelipat gandaan uang tidaklah bersifat konstan. Angka tersebut senantiasa berubah-ubah sejalan dengan pola interaksi antara otoritas, bank umum dan masyarakat. Dalam pengendalian mekanisme transmisi kebijakan moneter diperlukan instrumen instrumen untuk mengatur jumlah uang yang beredar. Salah satunya dalam penelitian ini adalah dengan instrumen Operasi Pasar Terbuka (OPT), dengan OPT sebagai 
instrumen moneter secara tidak langsung, dapat mempengaruhi sasaran operasionalnya yaitu suku bunga atau jumlah uang beredar secara lebih efektif. Dengan menggunakan Sertifikat Bank Indonesia (SBI) sebagai instrument moneter konvensional dan Sertifikat Bank Indonesia Syariah (SBIS) sebagai instrumen moneter syariah. Dengan Sertifikat Bank Indonesia (SBI) dan Sertifikat Bank Indonesia Syariah (SBIS) bank sentral melakukakan kegiatan jual beli surat-surat berharga dengan pelaku pasar, baik di pasar primer maupun sekunder yang dijadikan instrumen operasional tidak langsung utama pengendalian moneter.

Untuk mengendalikan inflasi, jumlah uang yang beredar (M2) agar lebih efektif dan bermanfaat harus disalurkan dalam kegiatan ekonomi. Seperti yang telah disebutkan sebelumnya, di Indonesia memiliki berbagai macam saluran, salah satunya adalah melalui saluran harga aset yang akan digunakan dalam penelitian ini. Dimana melalui perubahan-perubahan instrumen moneter dan target operasionalnya mempengaruhi berbagai variabel ekonomi dan keuangan sebelum akhirnya berpengaruh ke tujuan akhir inflasi. (Bank Indonesia, 2015).

Bank sentral menjalankan kebijakan moneter, mereka melakukan serangkaian pengaturan atau penyesuaian ekonomi yang bekerja di pasar barang maupun pasar aset. Penerapan kebijakan moneter mempengaruhi pembelanjaan, output, dan penyerapan sumber daya (employment) dalam jangka pendek, yang berujung pada perubahan tingkat harga dalam jangka menengah dan jangka panjang. Adapun pengaruhnya kebijakan moneter yang dilakukan $\mathrm{BI}$ dalam mempengaruhi harga aset sebelum hasil akhir menentukan tingkat inflasi.

Menurut Pohan (2008), menjaga kestabilan nilai uang ini bukanlah masalah yang sederhana, karena uang berkaitan erat dengan hampir seluruh aspek dalam perekonomian. Dan alasan ini pula, proses kebijakan moneter sampai menyentuh kepada sektor riil menjadi masalah yang sangat kompleks dan tidak mudah pula menjaga stabilitas harga pada kondisi inflasi yang aman. Proses ini kemudian lazim disebut sebagai mekanisme transmisi kebijakan moneter, yang merupakan saluran penghubung kebijakan moneter ke perekonomian riil. Permasalahan mengenai mekanisme transmisi kebijakan moneter ini masih merupakan topik yang menarik dan menjadi perdebatan, baik di kalangan akademis maupun para praktisi seperti Taylor: 2000, Warjiyo dan Agung: 2002, Muelgini: 2004, Mishkin: 2004, Doni Satria dan Solikin M. Juhro:2011, serta Ascarya: 2012. 
Menariknya Mekanisme Transmisi Kebijakan Moneter selalu dikaitkan dengan dua pertanyaan. Pertama, apakah kebijakan moneter dapat mempengaruhi ekonomi riil di samping pengaruhnya terhadap harga. Kedua, jika jawabannya ya, maka melalui mekanisme transmisi yang manakah pengaruh kebijakan moneter terhadap ekonomi riil tersebut terjadi. (Deswita, 2013).

Pada penelitian ini akan menganalisis dan mengolah data dengan uji Vector Autoregressive (VAR). VAR merupakan model ekonometrika yang digunakan dalam analisis kebijakan makroekonomi dinamik dan stokastik. VAR merupakan sistemsistem persamaan yang memperlihatkan setiap variabel sebagai fungsi linier dari konstanta dan nilai lag (lampau) dari variabel itu sendiri, serta nilai lag dari variabel lain yang ada dalam sistem (Siregar dan Irawan, 2005). Variabel penjelas dalam VAR meliputi nilai lag dari variabel lain yang ada dalam sistem VAR yang membutuhkan identifikasi retriks untuk mencapai persamaan melalui interpretasi persamaan. (Ajija,dkk, 2011).

Asumsi yang harus dipenuhi dalam analisis VAR adalah semua variabel tak bebas bersifat stasioner, semua sisaan bersifat white noise, yaitu memliki rerataan nol, ragam konstan, dan diantara variabel tak bebas tidak ada korelasi. Uji kestasioneran data dapat dilakukan melalui pengujian terhadap ada tidaknya unit root dalam variabel dengan diuji Augmented Dekey fuller (ADF), adanya unit root akan menghasilkan persamaan atau model regresi yang lancung. (Ajija,dkk, 2011). Pendekatan VAR sangat lazim digunakan untuk meneliti dampak kebijakan moneter terhadap variabel ekonomi lainnya yang banyak ditunjuk oleh peneliti lain untuk menganalisa hubungan dan dampak kebijakan moneter. Seperti dalam penelitian ini yang menggunakan alat transmisi kebijakan moneter konvensional dan syariah melalui jalur aset dalam mempengaruhi stabilitas harga (inflasi).

Pendekatan yang digunakan untuk mengatasi persamaan regresi lancung adalah dengan melakukan deferensiasi atas variabel endogen dan eksogennya. Sehingga diperoleh variabel yang stasioner dengan derajat $I(n)$. Kestasioneran data melalui pendefernsian belum cukup, kita perlu mempertimbangkan keberadaan hubungan jangka panjang dan pendek dalam model. (Ajija,dkk, 2011). Pendeteksian keberadaan kointegrasi ini dapat dilakukan dengan metode Johansen atau Engel Grenger. Jika variabel-variabel tidak terkointegrasi, maka dapat diterapkan VAR standar yang hasilnya akan identik dengan OLS, setelah memastikan variabel 
tersebut sudah stasioner pada derajat yang sama. Jika pengujian membuktikan terdapat vektor kointegrasi, maka dapat diterapkan ECM untuk single equation atau VECM untuk sistem equation.

Model yang digunakan dalam penelitian ini dibagi menjadi dua model, yaitu mekanisme transmisi moneter konvensional dan syariah. Dengan model pertama yaitu mekanisme transmisi moneter konvensional melalui jalur harga aset terhadap inflasi dan model kedua yaitu mekanisme transmisi moneter syariah melalui jalur harga aset terhadap inflasi. Model I dan II dijabarkan dalam tabel sebagai berikut:

\section{Tabel 1}

\section{Model Penelitian Mekanisme Transmisi Moneter Melalui Jalur Harga Aset}

\begin{tabular}{cc}
\hline Model & \multicolumn{1}{c}{ Penjabaran } \\
\hline I & $\mathrm{IHKt}=f($ SBlt, M2t, Obligasit $)$ \\
II & $\mathrm{IHK} \mathrm{K}_{\mathrm{t}}=f(\mathrm{SBISt}, \mathrm{M} 2 \mathrm{t}$, Sukukt $)$ \\
\hline
\end{tabular}

\section{HASIL DAN PEMBAHASAN}

Hasil dari uji stationer untuk keenam variabel menyimpulkan bahwa tidak ada variabel yang stationer pada tingkatan level. Untuk alasan tersebut, maka dilakukan uji integrasi pada first difference. Pada tingkat first difference semua veriabel telah stasioner, yaitu variabel LSBI, LSBIS, LM2, LOBL, LSKK dan LIHK. Hal ini diihat dari nilai probabilitas ADF seluruh variabel, yaitu menunjukkan nilai kurang dari $\alpha=0,05$, maka semua variabel tidak terjadi unit root pada tingkat first difference. Hasil menunjukan bahwa tidak terdapathubungan kointegrasi pada Model I. Hal ini dikarenakan nilai probabilitas berada diatas nilai probabilitas $\alpha=5 \%$. Sehingga untuk uji selanjutnya tidak dapat lanjut untuk uji jangka panjang yaitu pada uji VECM, namun hanya sampai uji VAR saja.

Hasil lain menunjukan bahwa juga tidak terdapat hubungan kointegrasi pada Model II. Hal ini dikarenakan nilai probabilitas berada diatas nilai probabilitas a $=5 \%$. Sehingga untuk uji selanjutnya tidak dapat lanjut untuk uji jangka panjang yaitu pada uji VECM, namun hanya sampai pada uji VAR saja. Dari hasil uji kointegrasi sebelumnya terbukti bahwa tidak terdapat kointegrasi pada kedua model. Untuk itu digunakanlah model VAR untuk menganalisis responsivitas Inflasi (IHK) terhadap instrumen moneter dalam mekanisme transmisi moneter. Dengan 
analisis VAR dapat diketahui hubungan jangka pendek saja antar variabel.

Berdasarkan hasil empiris dapat diketahui bahwa, variabel inflasi (IHK) memiliki pengaruh yang besar terhadap variabel itu sendiri. Berdasarkan hasil terlihat bahwa variabel mekanisme transmisi moneter seperti M2 dan obligasi dalam jangka pendek dapat mempengaruhi IHK sebagai indikator inflasi.Hal tersebut dikarenakan nilai t-statistik pada setiap variabel lebih besar dari nilai $t-$ tabelnya. Sedangkan variabel mekanisme transmisi moneter SBI dalam jangka pendek tidak memiliki pengaruh terhadap IHK sebagai indikator inflasi. Dalam hal sebaliknya SBI dalam jangka pendek dipengaruhi oleh IHK sebagai indikator inflasi.

Hasil impulse response function (IRF) untuk alur transmisi kebijakan moneter ganda menunjukan, jika mengalami tren negatif artinya adalah variabel tersebut mempengaruhi kenaikan inflasi (IHK), sedangkan jika mengalami tren positif artinya adalah variabel tersebut mempengaruhi penurunan inflasi (IHK). Hasil IRF pada variabel-variabel dalam Model I adalah sebagai berikut: pertama, SBI pada awal periode menunjukan tren negatif hingga pada periode ketiga menunjukan tren positif. Lalu pada periode ke-20 kembali pada tren negatif dan stabil juga permanen. Kedua, M2 pada awal peride menunjukan tren positif, namun pada periode ke-20 menunjukan tren negatif dan stabil juga permanen. Ketiga, obligasi pada awal periode menunjukan tren negatif, hingga pada periode ke-23 menunjukan tren positif dan stabil juga permanen.

Sedangkan untuk model 2, hasil impulse response function (IRF) untuk alur transmisi kebijakan moneter ganda menunjukan, jika mengalami tren negatif artinya adalah variabel tersebut mempengaruhi kenaikan inflasi, sedangkan jika mengalami tren positif artinya adalah variabel tersebut mempengaruhi penurunan inflasi. Hasil IRF pada variabel-variabel dalam Model 2 adalah sebagai berikut: pertama, SBIS pada awal periode menunjukan tren negatif, hingga pada periode ke- 21 menunjukan tren positif dan stabil juga permanen. Kedua, M2 pada awal periode menunjukan tren positif, namun pada periode ke-8 menunjukan tren negatif dan stabil juga permanen. Ketiga, Sukuk pada awal periode menunjukan tren negatif, hingga pada periode ke-21 menunjukan tren positif dan stabil juga permanen. 
Hasil penelitian IRF ini menunjukan kesamaan dengan penelitian yang dilakukan oleh Ascarya mengenai transmisi moneter pada jalur suku bunga (2012), dalam uji IRF nya menunjukan bahwa semua variabel konvensional memberikan dampak inflationer terhadap inflasi dan bersifat permanen. Pada sisi lain, semua variabel syariah memiliki dampak positif dalam pengertian berdampak menurunkan inflasi dan juga bersifat permanen. Meskipun pada jalur yang berbeda dalam mekanisme transmisi moneternya, namun memiliki kesimpulan dalam uji IRF yang sama.

Hasil Variance Decomposition menunjukkan variabel apa saja dan seberapa besar variabel tersebut memengaruhi variabel inflasi (IHK), dalam alur mekanisme transmisi moneter jalur harga aset konvensional. Pada periode pertama terlihat bahwa inflasi dapat dijelaskan oleh SBI sebesar $4.55 \%$ sampai pada periode akhir inflasi dapat dijelaskan oleh SBI sebesar $18.67 \%$. Selanjutnya dapat dlihat periode pertama inflasi dapat dijelaskan oleh M2 sebesar $0.042 \%$ dan semakin peningkatan pengaruh pada periode akhir sebesar $12.08 \%$. Selanjutnya dapat dilihat pula periode pertama inflasi dapat dijelaskan oleh obligasi sebesar $0.33 \%$ dan meningkat sebesar $13.12 \%$ pada akhir periode. Periode pertama inflasi dapat dijelaskan oleh inflasi itu sendiri sebesar $95.09 \%$ dan semakin menurun pengaruh pada periode akhir sebesar $56.13 \%$. Jadi pada model I, Variabel inflasi sebagai indikator inflasi sebagian besar dipengaruhi oleh variabel SBI sebesar $18.67 \%$. Hal ini mengindikasikan bahwa sepanjang periode tersebut pengaruh variabel SBI, M2 dan emisi obligasi terhadap inflasi akan semakin besar. Hal ini dikarenakan inflasi mendapatkan pengaruh langsung dari semua variabel yang diajukan tersebut sebagai instrumen dan jalur moneter konvensional yang berpengaruh pada transmisi moneter. Hal ini juga memberikan kesimpulan dari tabel bahwa variabel- variabel konvensional meliputi SBI (18.67\%), M2 (12.07\%), obligasi (13.12\%) yang memberikan sumbangan negatif (menaikan) inflasi sebesar $43.86 \%$.

Hasil variance decompotition dari variabel inflasi untuk model II menjelaskan pada periode pertama terlihat bahwa inflasi dapat dijelaskan oleh SBIS sebesar $3.75 \%$ dan di periode akhir terjadi penurunan, inflasi dapat dijelaskan oleh SBIS sebesar $3.18 \%$. Pada periode pertama inflasi dapat dijelaskan oleh M2 sebesar $0.019 \%$ dan semakin peningkatan pengaruh pada periode akhir sebesar $11.65 \%$. Pada periode pertama inflasi dapat dijelaskan oleh sukuk sebesar $0.55 \%$ dan mengalami kenaikan sebesar 
10.94\%. Periode pertama inflasi dapat dijelaskan oleh inflasi itu sendiri sebesar $95.99 \%$ dan semakin menurun pengaruh pada periode akhir sebesar $74.22 \%$. Jadi pada model II, Variabel inflasi sebagian besar dipengaruhi oleh variabel jumlah uang beredar (M2) sebesar $11.65 \%$.

Dalam periode tersebut pengaruh variabel SBIS, M2 dan emisi sukuk terhadap inflasi akan semakin besar. Inflasi mendapatkan pengaruh langsung dari semua variabel yang diajukan tersebut sebagai alat mekanisme transmisi moneter jalur harga aset syariah. Hal ini juga memberikan kesimpulan bahwa variabel-variabel syariah meliputi SBIS (3.18\%), M2 (11.65\%), sukuk (10.94\%) yang memberikan sumbangan positif (menurunkan) inflasi sebesar $25.77 \%$.

Hasil uji variance decomposite dalam penelitian ini pada transmisi moneter syariah jalur aset yang memiliki pengendalian menurunkan inflasi (IHK) yang lebih besar dibanding pengendalian menurunkan inflasi (IHK) transmisi moneter syariah pada jalur suku bunga pada penelitian yang dilakukan oleh Ascarya (2012). Pada mekanisme transmisi moneter pada jalur harga aset menyumbang penurunan inflasi sebesar $25.77 \%$, sedangkan mekanisme transmisi moneter pada jalur suku bunga hanya menyumbang penurunan inflasi sebesar $6.21 \%$.

Mekanisme transmisi moneter konvensional pada jalur harga aset memilki penyumbang menaikan inflasi lebih kecil dibanding mekanisme transmisi moneter konvensional pada jalur suku bunga. Pada mekanisme transmisi moneter konvensional pada jalur harga aset menyumbang kenaikan inflasi (IHK) sebesar 43.86\%. Sedangkan mekanisme transmisi moneter konvensional pada jalur suku bunga menyumbang kenaikan inflasi (IHK) sebesar $48.25 \%$. Sehingga mekanisme transmisi moneter jalur harga aset syariah memiliki alat atau instrumen moneter yang lebih baik untuk mengendalikan inflasi (IHK) dibanding mekanisme transmisi moneter jalur harga aset konvensional.

Variabel-variabel konvensional tersebut masih sangat dipengaruhi oleh tingkat suku bunga yang ditentukan dalam mekanisme pasar, terlihat bahwa dari karakterisik SBI dapat diperdagangkan dipasar sekunder yang memiliki pula sifat spekulatif. Sedangkan obligasi adalah jual beli surat utang dimana tidak 
memiliki aset berwujud tertentu dalam kegiatan investasinya dan tentunya harga obligasi dipengaruhi oleh tingkat suku bunga bank. Sehingga tidak diragukan lagi bahwa model I dengan variabel-variabel konvensional berdampak menimbulkan inflasi.

Sedangkan mekanisme transmisi moneter syariah melalui jalur harga aset dalam mengendalikan inflasi dengan uji IRF (model 2), variabel-variabel syariah yaitu SBIS, M2 dan sukuk yang dijadikan indikator memiliki dampak positif dalam arti variabel-variabel tersebut mengurnagi dampak kenaikan IHK sebagai indikator inflasi dan bersifat permanen pada periode tersebut. Begitu pula dengan SBIS pada akhir periode mendekati negatif dalam mempengaruhi inflasi, namun pada sisi syariah ini berhasil mempengaruhi menurunkan inflasi sebesar $25.77 \%$. Dengan begitu implikasinya adalah ketika inflasi berhasil diturunkan maka daya beli masyarakat akan barang dan jasa akan meningkat. Dalam uji VAR penelitian kali ini menyimpulkan masih lebih efektif mekanisme transmisi moneter syariah di bandingkan dengan konvensionl dan masih lebih baik menggunakan saluran harga aset dibanding saluran suku bunga untuk mekanisme transmisi moneter dalam mengendalikan inflasi (IHK).

\section{SIMPULAN}

Hasil estimasi VAR dapat disimpulkan bahwa pada mekanisme transmisi moneter syariah (model II) tidak memiliki pengaruh baik dari variabel mekanisme transmisi moneter syariah terhadap inflasi (IHK) maupun variabel inflasi terhadap variabel mekanisme transmisi moneter syariahnya. Dalam uji variance decomposition dalam mekanisme transmisi moneter konvensional model I terhadap inflasi, variabel yang diajukan pada model I penelitian ini dapat disimpulkan bahwa variabel-variabel konvensional meliputi SBI (18.67\%), M2 (12.07\%), obligasi (13.12\%) yang memberikan sumbangan negatif (menaikan) inflasi sebesar $43.86 \%$. Sedangkan Dalam uji variance decomposition dalam mekanisme transmisi moneter model II terhadap inflasi, variabel-variabelnya juga memberikan kesimpulan bahwa variabelvariabel syariah meliputi SBIS (3.18\%), M2 (11.65\%), sukuk (10.94\%) yang memberikan sumbangan positif (menurunkan) inflasi sebesar 25,77\%. Sehingga dapat dikatakan bedasarkan hasil uji VAR dalam penelitian ini, alur mekanisme transmisi moneter syariah melalui jalur harga aset memiliki mekanisme yang lebih baik dibanding dengan alur mekanisme transmisi moneter 
konvensional melalui jalur harga aset dalam mempengaruhi IHK sebagai indikator inflasi.

Perlunya memperhatikan instrumen-instrumen moneter yang diambil bank sentral, baik instrumen kebijakan moneter konvensional maupun instrumen kebijakan moneter syariah guna mengatur jumlah uang yang beredar. Karena instrumen yang digunakan dalam mekanisme transmisi moneter baik konvensional maupun syariah pada jalur harga aset tersebut ternyata belum berpengaruh cukup besar dalam mengendalikan inflasi.

\section{PUSTAKA ACUAN}

Ajija, S.R, dkk. 2011. Cara Cerdas Menguasai Eviews. Jakarta: Salemba Empat.

Andra, H. 2010. Analisis Pengaruh Instrumen Kebijakan Moneter Konvensional dan Instrumen Kebijakan Moneter Islam Terhadap Kinerja Bank Konvensional dan Bank Syariah. Skripsi Tidak Dipublikasikan. Jakarta: UIN Syarif Hidayatullah.

Ascarya. 2005. Instrumen-Instrumen Pengendalian Moneter: Seri kebanksentralan". Jakarta: Bank Indonesia.

Ascarya. 2012. Buletin Ekonomi dan Perbankan: Alur Transmisi dan Efektifitas Kebijakan Moneter Ganda di Indonesia. Jakarta: Bank Indonesia.

Ascarya. 2014. Monetary Policy Transmission Mechanism under Dual Financial System in Indonesia: Interest-Profit Channel. Kuala Lumpur: The Internasional Islamic University of Malaysia.

Asif, dkk. 2005. Transmission Mechanism of Monetary Policy in Pakistan. Pakistan: The State Bank of Pakistan.

Awawin, M. 2014. Analisis Pengaruh Instrumen Moneter Syariah dan Konvensional Terhadap Penyaluran Dana ke Sektor Properti di Indonesia. Skripsi Tidak Dipublikasikan. Bogor: Institut Pertanian Bogor.

Bayuni, E. M. \& Ascarya. 2010. Analisis Pengaruh Instrumen MoneterTerhadap Stabilitas Besaran Moneter Dalam Sistem Moneter Ganda di Indonesia". TAZKiA: Islamic Finance and Bussines Review.

Herlina, D. 2013. Identifikasi Mekanisme Transmisi Kebijakan Moneter di Indonesia Tahun 2000 - 2011. Skripsi Tidak Dipublikasikan. Serang: Universitas Sultan Ageng Tirtayasa.

Nasrudin, A. 2012. Peran Pasar Modal Syariah dalam Transmisi Kebijakan Moneter Indonesia. Skripsi Tidak Dipublikasikan. Bogor: STEI TAZKIA. 
Ramadhan, M.M. 2012. Analisis Penagaruh Instrumen Moneter Syariah Dan Konvensional Terhadap Penyaluran ke Sektor Usaha Kecil dan Menengah (UMKM) Di Indonesia. (Skripsi Tidak Dipublikasikan). Bogor: Institut Pertanian Bogor.

Warjiyo, P. 2004. Mekanisme Transmisi Kebijakan Moneter di Indonesia. Jakarta: Pusat Pendidikan dan Studi Kebanksentralan Bank Indonesia 